\title{
THE COMBINATION OF ARBUSCULAR MYCORRHIZAL FUNGI WITH ROCK POWDER AND POULTRY LITTER: AN APPROPRIATE NATURAL FERTILISER FOR IMPROVING THE PRODUCTIVITY OF SOYBEAN (GLYCINE MAX (L.) MERR)
}

\author{
KAMDEM KAIGOM FABRICE, TCHUENTEU TATCHUM LUCIEN, MAIMOUNA ABBA, \\ MEGUENI CLAUTILDE*
}

University of Ngaoundere-Cameroon, Republic of Cameroon

\begin{abstract}
KAMDEM, K.F. - TCHUENTEU, T.L. - MAIMOUNA, A. - MEGUENI, C.: The combination of arbuscular mycorrhizal fungi with rock powder and poultry litter: An appropriate natural fertiliser for improving the productivity of soybean (Glycine $\max ($ L.) MERR). Agriculture (Pol'nohospodárstvo), vol. 66, no. 3, pp. $108-117$.
\end{abstract}

The present study aimed to evaluate the effect of the combination of various natural fertilisers on growth and seed yield of the soybean plants. Field experimentations were carried out during two cropping seasons (2018 and 2019). A randomized complete block experimental design with 11 treatments (F1: $30 \mathrm{~g}$ of poultry litter, F2: $60 \mathrm{~g}$ of poultry litter, MP: $10 \mathrm{~g}$ of mycorrhizae $+10 \mathrm{~g}$ of vivianite powder, MF1: $10 \mathrm{~g}$ of mycorrhizae $+30 \mathrm{~g}$ of poultry litter, MF2: $10 \mathrm{~g}$ of mycorrhizae $+60 \mathrm{~g}$ of poultry litter, PF1: $10 \mathrm{~g}$ of vivianite powder $+30 \mathrm{~g}$ of poultry litter, PF2: $10 \mathrm{~g}$ of vivianite powder $+60 \mathrm{~g}$ of poultry litter, MPF1: $10 \mathrm{~g}$ of mycorhizae $+10 \mathrm{~g}$ of vivianite powder $+30 \mathrm{~g}$ of poultry litter, MPF2: $10 \mathrm{~g}$ of mycorrhizae $+10 \mathrm{~g}$ of vivianite powder $+60 \mathrm{~g}$ of poultry litter, $\mathrm{T}+$ : chemical fertiliser, $\mathrm{T}-$ : unfertilised plants) and three replications were used. The growth parameters and seed yield were evaluated. The results showed that the growth and seed yield of soybean varied depending on the fertiliser and the cropping season. Plants that have received the MPF2 treatment exhibited significantly $(p<0.05)$ the highest values of the studied parameters (plants height, foliar production, plants dry biomass, seed yield). The MPF2 treatment increased the seed yield of soybean by $20.08 \%$ and $184.76 \%$ compared to $\mathrm{T}+$ and $\mathrm{T}-$ treatments, respectively. The supply of the following combination, $10 \mathrm{~g}$ of mycorrhizae $+10 \mathrm{~g}$ of vivianite powder $+60 \mathrm{~g}$ of poultry litter was found to be very promising in improving the soybean plant growth and therefore, can be used as an alternative to replacing the mineral fertilisers usually employed for the cultivation of this crop.

Key words: soybean, mycorrhizae, vivianite powder, poultry litter, growth, seed yield

In Northern Cameroon, cereals are considered as the basic foods for human and some animals. Although they provide important calories, they remain deficient in protein (Tien et al. 2002). Legumes constitute an excellent supplement in protein for a diet rich in cereal because they can provide between 18 and $38 \%$ of proteins (Watier 1982). For soybean in particular, up to $45 \%$ of the protein content has been reported (Roux 2002). Despite its high protein content, soybean production is challenged by many difficulties such as low soil fertility, insect pests, and the diseases. Synthetic chemicals are commonly used to control these constraints (Megueni et al. 2006). However, the extensive use of pesticides is a threat to environmental pollution and food contamination. Another risk related to the use of chemical

Kamdem Kaigom Fabrice, Tchuenteu Tatchum Lucien, Maimouna Abba and Megueni Clautilde (*Corresponding author), Department of Biological Sciences, Faculty of Science, University of Ngaoundere-Cameroon. E-mail: cmegueni2003@ yahoo.fr 
compounds is that plants can become resistant to these compounds and therefore, their application will no longer be effective. Although chemical fertilisers present immediate beneficial effect on crop productivity by providing an immediate solution to the declining soil fertility problem, their high cost and unavailability make them almost inaccessible to many farmers (Megueni et al. 2011). To avoid this situation, it becomes necessary to seek alternative fertilisers. In this respect, we have previously studied the effects of various doses of mycorrhizae and vivianite powder on soybean productivity in Ngaoundere (Cameroon) and the results indicated that these compounds can improve the growth and seed yield of soybean (Kamdem 2017).

The mycorrhizae are symbiotic associations between mycorrhizal fungi and plant roots. This biofertiliser produced by mycorrhizae improves plant production by promoting plants hydromineral nutrition (Sheng et al. 2008). Protective effects of mycorrhizae against pathogens, pests, and parasitic plants have also been described for many plant species, including agriculturally important crop varieties (Jung et al. 2012). Vivianite is an iron oxide and phosphate. Its chemical formula is $\mathrm{Fe}_{2}\left(\mathrm{PO}_{4}\right)_{2} 8 \mathrm{H}_{2} \mathrm{O}$. The benefic effects of vivianite powder in enhancing crop growth have been demonstrated (Yaya et al. 2015; Megueni et al. 2017). Phosphorus is one of the macronutrients essential for plant growth and development. It is the second most important microelement after nitrogen (Vassilev \& Vassileva 2003). The poultry litter is a mixture of the substrate, usually wood chips, with bird droppings, feathers, and leftover food. Due to its composition in nutrient elements and availability at low cost in our area of study (Ngaoundere-Cameroon), it can be used by farmers for crop fertilisation.

Before conducting this study, we hypothesized that the combination of mycorrhizae-vivianite powder-poultry litter could improve soil fertility as well as providing a protective role to crops against pests and thus, to enhance soybean production. The main objective of this study was to enhance soybean production through improved soil fertility by using natural fertiliser like mycorrhizal fungi, vivianite powder, and poultry litter.

\section{MATERIAL AND METHODS}

\section{Study site}

The study was conducted during two cropping seasons (2018 and 2019) in the experimental field of the University of Ngaoundere (Cameroon) located on its main campus. The area belongs to the agro-ecological zone II of Cameroon and is characterized by a Sudano-Guinean savannah with five months dry season (November to March) and seven months rainy season (April to October). The average annual temperature and total annual precipitations are $25.75^{\circ} \mathrm{C}$, and $1,898.6 \mathrm{~mm}$ (Derogoh et al. 2018), respectively. The followings are the geographical parameters of the field: $03^{\circ} 38^{\prime} 805^{\prime \prime}$ latitude, $08^{\circ} 20^{\prime} 806^{\prime \prime}$ longitude and 1,106.0 m elevation (altitude). The vegetation of the area is an herbaceous savannah dominated by Imperata cylindrica, Pennisetum purpureum, Annona senegalensis, and Piliostigma thonningii.

\section{Chemical properties of the soil from the field of study}

The chemical properties of the soil include the $\mathrm{pH}$ as well as $\mathrm{N}, \mathrm{P}, \mathrm{Ca}$, and $\mathrm{Mg}$ contents (Table 1). To evaluate the chemical properties of the growing soil, its $\mathrm{pH}$ was measured using a $\mathrm{pH}$ meter (Model ORION 230A - Range- $2-19.99 \pm 0.01$, USA). The total nitrogen content was determined after mineralization of the soil samples according to the method of Kjeldahl (AFNOR 1984) and the dosage was carried out according to the calorimetric technique of Devani et al. (1989). The total phosphorus content was assessed following the methods described by Rodier (1978). Assessment of calcium and magnesium were carried out by titration with Ethylene Diamine TetraAcetic (AFNOR 1986).

$\mathrm{N}$ and $\mathrm{P}$ were the main components of the cropped soil. The $\mathrm{pH}$ of the soil where the study was conducted was acidic and this conformed with some previous founding documented in the literature (Olina et al. 2008; Mbonigaba et al. 2009). Indeed, Olina et al. (2008) revealed that the average soil pH in Far North Cameroon was acidic (6) and Mbonigaba et al. (2009) reported that acidity is one of the characteristics of tropical soils. In addition, Abakar et al. (2019) studied the response of two cot- 
ton varieties on mycorrhizal inoculation in Soudano-Sahelian savannah of Cameroon and found that soils from Kodek and Mouda localities were acid. The acidity of the soil is caused by many factors including the deficiencies in $\mathrm{N}, \mathrm{P}, \mathrm{K}, \mathrm{Ca}, \mathrm{Mg}$, and Mo. Acidity reduces the fixation of biological nitrogen and acid soils are susceptible to erosion (Nanda \& Adriano 2014). Giller and Dashiell (2007) found that the optimum $\mathrm{pH}$ for soybean growth ranged between 5.5-7.5 and therefore soybeans would be very sensitive to low $\mathrm{pH}(\mathrm{pH}<5.5)$, thus suggesting that soil from our study site was not favorable for soybean production. The data of the soil chemical properties obtained in the current study are instruc- tive for improving the soil fertility to optimize the growth and development of soybean.

\section{Material}

\section{Soybean seeds}

Soybean seeds (average $5 \mathrm{~mm}$ length and $5 \mathrm{~mm}$ maximum diameter) variety SJ235 was bought on the local market of Ngaoundere-Cameroon. This variety was chosen for its early germination, great adaptability to the rainy season, and has a short reproduction cycle (105-110 days). Using the variety that has a short reproduction cycle is advantageous for the farmers as it can favor multiple cropping per year provided that there is a possibility for off-season crops (Tchuenteu et al. 2018).

\section{$\mathrm{T}$ a $\mathrm{b} 1 \mathrm{e}$}

Chemical properties of soil from experimental site

\begin{tabular}{|c|c|c|c|c|}
\hline $\mathrm{pH}$ & $\mathrm{N}_{\text {tot }}(\mathrm{g} / 100 \mathrm{~g})$ & $\mathrm{P}_{\text {tot }}(\mathrm{g} / 100 \mathrm{~g})$ & $\mathrm{Ca}(\mathrm{g} / 100 \mathrm{~g})$ & $\mathrm{Mg}(\mathrm{g} / 100 \mathrm{~g})$ \\
\hline $4.3 \pm 0.01$ & $4.23 \pm 0.59$ & $0.41 \pm 0.02$ & $0.49 \pm 0.00$ & $0.10 \pm 0.02$ \\
\hline
\end{tabular}

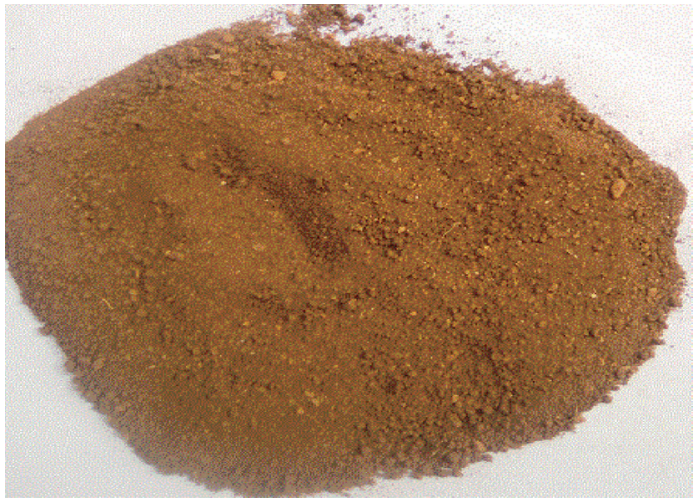

1A: Mycorrhizal inoculum

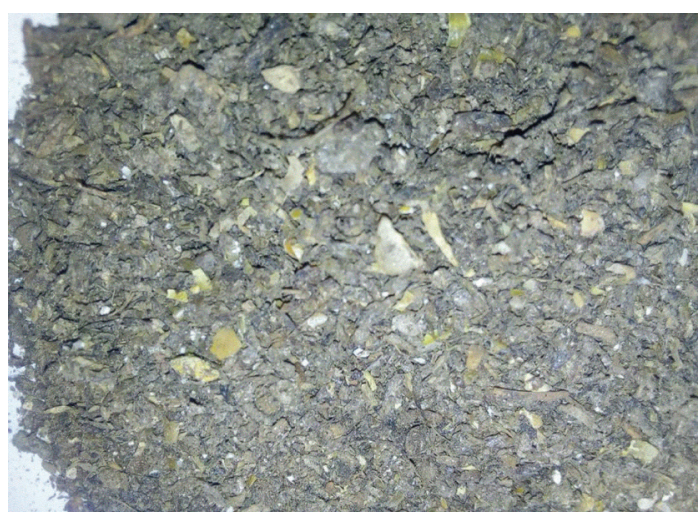

1C: Poultry litter

Figure 1. Fertilisers

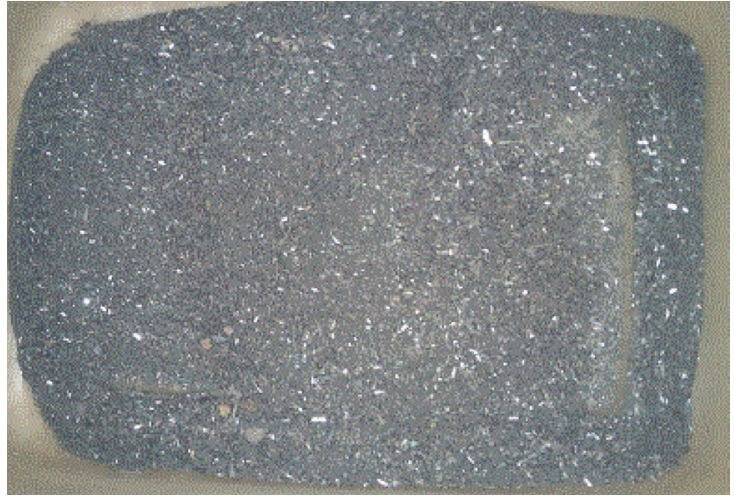

1B: Vivianite powder

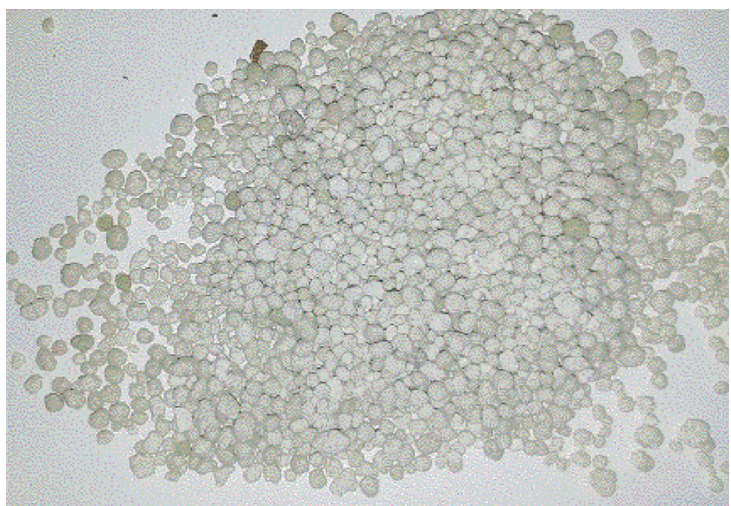

1D: Chemical fertiliser 
Fertilisers

The fertilisers used in the trials were inoculum of mycorrhizal fungi, rock powder, poultry litter, and a chemical fertiliser (NPK: 12-24-12) (Figure 2).

The mycorrhizal biofertilisers used in this work were supplied by the Laboratory of Soil and Microbiology of the Biotechnology Center of the University of Yaounde I (Cameroon) (Figure 1A). Selected isolates were multiplied by sorghum and peanut plants (host plants) and tested on maize and sorghum (Nwaga et al. 2007). It contains infective spores and propagules of three genus Glomus, Scutellospora, and Gigaspora species with a concentration of approximately 20 spores/g of substrate.

The mineral fertilisers were the rock powders obtained from vivianite (Figure 1B). The rocks were sampled from the Hangloa Basin located at about $25 \mathrm{~km}$ in the Northwest of the city of Ngaoundere. These rocks are characterized by a flattened ellipsoid form with their diameters ranging from $20 \mathrm{~cm}$ to more than one meter. The chemical analyses of the powder derived from these rocks were conducted earlier by Yaya et al. (2015) and gives the following composition: $\mathrm{Fe}_{2} \mathrm{O}_{3}(68.72 \%), \mathrm{P}_{2} \mathrm{O}_{5}(9.17 \%), \mathrm{Al}_{2} \mathrm{O}_{3}$ (7.72\%), and $\mathrm{SiO}_{2}(9.67 \%)$. Thus, the total phosphorus was estimated at about $671.50 \mathrm{mg} / \mathrm{kg}$ while the assimilated phosphorus was around $81.13 \mathrm{mg} / \mathrm{kg}$. Studies carried out by Yaya et al. (2015) indicated that phosphate contained in this mineral can be solubilized.

Poultry litter (Figure 1C) from a henhouse located near the campus of the University of Ngaoundere was collected from 8 to 9 am daily according to its availability and then stored in $50 \mathrm{~kg}$ bag before been transported to the experimental area using a rickshaw.

Chemical fertiliser (Figure 1D) was bought on the local market in Ngaoundere. The main nutrients of the fertiliser are Nitrogen $(\mathrm{N})$, phosphorus $(\mathrm{P})$, and potassium $(\mathrm{K})$. It is referred to as NPK (12-2412) chemical fertiliser, meaning that it contained $12 \% \mathrm{~N}, 24 \% \mathrm{P}_{2} \mathrm{O}_{5}$, and $12 \% \mathrm{~K}_{2} \mathrm{O}$ ).

\section{Methods}

Evaluation of the responses of soybean to mycorrhizal fungi, rock powder, and poultry litter

Land preparation and experimental design. Field experimentation was carried out during two cropping seasons 2018 and 2019. The experimental site measured $102.6 \mathrm{~m}^{2}$ area $(13.5 \mathrm{~m} \times 7.6 \mathrm{~m})$. The experimental field was ploughed at $50 \mathrm{~cm}$ depth and the elementary plots of $2.2 \mathrm{~m}^{2}$ area $(2.2 \mathrm{~m} \times 1 \mathrm{~m})$ were formed. 33 experimental units were formed. A randomized complete block experimental design with 11 treatments (F1:30 g of poultry litter, F2: $60 \mathrm{~g}$ of poultry litter, MP: $10 \mathrm{~g}$ of mycorrhizae $+10 \mathrm{~g}$ of vivianite powder, MF1: $10 \mathrm{~g}$ of mycorrhizae $+10 \mathrm{~g}$ of poultry litter, MF2: $10 \mathrm{~g}$ of mycorrhizae $+60 \mathrm{~g}$ of poultry litter, PF1: $10 \mathrm{~g}$ of vivianite powder $+30 \mathrm{~g}$ poultry litter, $\mathrm{PF} 2: 10 \mathrm{~g}$ of vivianite powder $+60 \mathrm{~g}$ of poultry litter, MPF1: $10 \mathrm{~g}$ of mycorrhizae $+10 \mathrm{~g}$ of vivianite powder $+30 \mathrm{~g}$ of poultry litter, MPF2: 10 $\mathrm{g}$ of mycorrhizae $+10 \mathrm{~g}$ of vivianite powder $+60 \mathrm{~g}$ of poultry litter, $\mathrm{T}+$ : chemical fertiliser, $\mathrm{T}-$ : unfertilised plants) and three replications were used. The space between two consecutive plants in an experimental unit was $20 \mathrm{~cm}$. There were 40 soybean plants per experimental unit (about 250,000 plants/ha). Seeds were sown at $3 \mathrm{~cm}$ depth and 2 soybean seeds were sown per hole, and thus 80 seeds per experimental unit.

\section{Sampling, data collection, and statistical analysis}

During the vegetative phase, 30 plants were randomly selected and plant height and the number of leaves per plant were measured and counted, respectively. This was done at a regular interval of 14 days starting from the $14^{\text {th }}$ day after sowing. The dry biomass of soybean plants was evaluated at flowering on 10 plants located around the center of each plot. At maturity, seed yield was assessed.

For the assessment of the dry biomass of soybean, plants were first removed from the soil with their rhizosphere and then the roots were washed. The clean plants (with soil-free roots) were wrapped in newspaper and then dried in an oven at $105^{\circ} \mathrm{C}$. During the drying process and starting from the first 24 hours, plants were regularly weighed until constant weights were obtained. The dry matter noted MS ( $\mathrm{g} / 100 \mathrm{~g})$ is expressed as follows:

$$
\mathrm{MS}=\frac{(\mathrm{M} 2-\mathrm{M} 0)}{(\mathrm{M} 1-\mathrm{M} 0)} \times 100
$$

where: $\mathrm{M} 0=$ mass in grams of empty the capsule; M1 = mass in grams of capsule containing the test sample before drying; M2 = mass in grams of the 
capsule containing the test sample after drying and cooling. 10 plants were sampled.

Soybean seed yield was assessed at maturity on a sample of 30 plants using this formula:

$$
\mathrm{R}(\mathrm{t} / \mathrm{ha})=\mathrm{Q} \times 250,000
$$

where: $\mathrm{R}=$ seed yield estimated in $\mathrm{t} / \mathrm{ha} ; \mathrm{Q}=$ average seed weight per plant and 250,000 = number of plants per hectare.

All the data were statistically analyzed using the Stagraphic plus Program version 5.0. The significance of differences was determined using Duncan test.

\section{RESULTS AND DISCUSSION}

Effects of the fertilisers on the growth parameters of soybean

The growth parameters of soybean plants were assessed at 70 days after sowing. The analysis of variance (ANOVA) revealed that the evaluated parameters (plant height, number of leaves per plant, dry biomass of plant) varied significantly $(p<0.05)$ depending on the fertiliser used. Soybean plants treated with the mixture of $10 \mathrm{~g}$ of mycorrhizae + $10 \mathrm{~g}$ of vivianite powder $+60 \mathrm{~g}$ of poultry litter exhibited significantly the greatest growth parameters. There is no significant difference between the cropping season within a year relative to the studied growth parameters such as plant height and foliar production. However, the year of experimentation affected significantly $(p<0.05)$ the soybean dry biomass.

\section{Plants height}

The average plant heights were $116.66 \pm 13.76 \mathrm{~cm}$ and $111.76 \pm 10.13 \mathrm{~cm}$ for the 2018 and 2019 cropping seasons, respectively. Unfertilised plants (T-) exhibited the lowest average value $(90.32 \pm 9.16 \mathrm{~cm})$. Among the natural fertilisers used, the combination of $10 \mathrm{~g}$ of mycorrhizae $+10 \mathrm{~g}$ of vivianite powder

$\mathrm{T}$ a b 1 e 2

Average plant height depending on the fertiliser used and the cropping season

\begin{tabular}{|l|c|c|c|}
\hline \multirow{2}{*}{ Fertilisers } & \multicolumn{2}{|c|}{ Plant height $[\mathrm{cm}]$} & Mean \pm SD \\
\cline { 2 - 4 } T- & 2018 cropping season & 2019 cropping season & $90.32 \pm 9.16^{\mathrm{a}}$ \\
T+ & $82.65 \pm 7.21$ & $98.00 \pm 10.021$ & $129.05 \pm 10.25^{\mathrm{c}}$ \\
F1 & $125.70 \pm 9.22$ & $132.40 \pm 9.32$ & $100.18 \pm 8.201^{\mathrm{b}}$ \\
F2 & $100.70 \pm 9.02$ & $99.67 \pm 8.33$ & $115.16 \pm 10.31 \mathrm{~b}^{\mathrm{c}}$ \\
MP & $115.33 \pm 9.04$ & $114.99 \pm 9.09$ & $114.66 \pm 9.22 \mathrm{~b}^{\mathrm{c}}$ \\
PF1 & $115.66 \pm 9.01$ & $113.67 \pm 9.02$ & $116.03 \pm 6.87^{\mathrm{c}}$ \\
PF2 & $114.77 \pm 8.90$ & $117.29 \pm 8.02$ & $120.66 \pm 7.89^{\mathrm{c}}$ \\
MF1 & $130.33 \pm 9.01$ & $111.00 \pm 7.021$ & $111.00 \pm 7.35^{\mathrm{bc}}$ \\
MF2 & $124.67 \pm 9.02$ & $97.33 \pm 8.26$ & $122.96 \pm 8.42^{\mathrm{c}}$ \\
MPF1 & $130.33 \pm 7.24$ & $115.59 \pm 7.21$ & $112.19 \pm 9.61^{\mathrm{bc}}$ \\
MPF2 & $114.67 \pm 8.25$ & $109.71 \pm 6.89$ & $124.99 \pm 6.22^{\mathrm{bc}}$ \\
Mean \pm SD & $128.65 \pm 9.02$ & $121.33 \pm 10.01$ & $113.27 \pm 9.021$ \\
\hline
\end{tabular}

SD - Standard deviation; F1 - $30 \mathrm{~g}$ of poultry litter; F2 - $60 \mathrm{~g}$ of poultry litter; MP - the combination $10 \mathrm{~g}$ of mycorrhizae $+10 \mathrm{~g}$ of vivianite powder; MF1 - the combination $10 \mathrm{~g}$ of mycorrhizae $+10 \mathrm{~g}$ of poultry litter; MF2 - the combination $10 \mathrm{~g}$ of mycorrhizae $+60 \mathrm{~g}$ of poultry litter; PF $1-10 \mathrm{~g}$ of vivianite powder $+30 \mathrm{~g}$ poultry litter; PF $2-10 \mathrm{~g}$ of vivianite powder $+60 \mathrm{~g}$ of poultry litter; MPF $1-10 \mathrm{~g}$ of mycorrhizae $+10 \mathrm{~g}$ of vivianite powder $+30 \mathrm{~g}$ of poultry litter; MPF $2-10 \mathrm{~g}$ of mycorrhizae $+10 \mathrm{~g}$ of vivianite powder $+60 \mathrm{~g}$ of poultry litter; $\mathrm{T}+-$ chemical fertiliser; $\mathrm{T}-$ unfertilised plants. Values of columns affected by the same letter are not significantly different. 
$+60 \mathrm{~g}$ of poultry litter (MPF2) exhibited the highest average plant height $(124.99 \pm 6.22 \mathrm{~cm})$. The mean height of the plants treated by chemical fertiliser $(\mathrm{T}+)$ was $129.05 \pm 10.25 \mathrm{~cm}$. There was no significant difference between MPF2 and $\mathrm{T}+$ when comparing the plant height of the two treatments. The combination of poultry litter with mycorrhizae or vivianite powder increases the plant height than the employment of poultry litter alone. MPF2 plants were 1.39 fold taller than $\mathrm{T}$-plants (Table 2).

\section{Number of leaves per plant}

The average numbers of leaves per plant were $117.21 \pm 11.677$ and $118.00 \pm 11.677$ for the 2018 and 2019 growing seasons, respectively (Figure 2). The numbers of leaves per plant for the single treatment F1 and F2 (30 g and $60 \mathrm{~g}$ of poultry litter) as the bio-fertiliser poultry on one hand and the following combinations: $\mathrm{MP}=10 \mathrm{~g}$ of mycorrhizae + $10 \mathrm{~g}$ of vivianite powder, MF1 $=10 \mathrm{~g}$ of mycorrhi$\mathrm{zae}+30 \mathrm{~g}$ of poultry litter, MF2 $=10 \mathrm{~g}$ of mycorrhi$\mathrm{zae}+60 \mathrm{~g}$ of poultry litter, PF $1=10 \mathrm{~g}$ of vivianite powder +30 g poultry litter, $\mathrm{PF} 2=10 \mathrm{~g}$ of vivianite powder $+60 \mathrm{~g}$ of poultry litter, MPF $1=10 \mathrm{~g}$ of mycorhizae $+10 \mathrm{~g}$ of vivianite powder $+30 \mathrm{~g}$ of poultry litter, MPF $2=10 \mathrm{~g}$ of mycorrhizae $+10 \mathrm{~g}$ of vivianite powder $+60 \mathrm{~g}$ of poultry litter on the other hand were $98.83 \pm 9.04,117.33 \pm 9.86,116.00 \pm 9.83$,
$124.99 \pm 10.68, \quad 120.16 \pm 8.87, \quad 117.00 \pm 11.12$, $123.83 \pm 8.58,119.00 \pm 7.68,127.50 \pm 8.22$, respectively. The average leaves per plant obtained for the treatment using the chemical fertiliser $(\mathrm{T}+)$ and for the unfertilised plants $(\mathrm{T}-)$ were $145.16 \pm 9.83$ and $84.16 \pm 8.33$, respectively. Among the treatments using the natural fertilisers, plants under MPF2 treatment exhibited the greatest foliar production and the average number of leaves per plant for the same treatment (MPF2) was 1.51 fold greater than the one obtained for the control plot $(\mathrm{T}-)$ where none of the fertiliser was added.

\section{Dry biomass of the soybean plants}

The results of the dry biomass are presented in Figure 3. The average biomass for 2018 and 2019 cropping years were $41.66 \pm 7.06 \mathrm{~g} /$ plant and $61.66 \pm 7.07 \mathrm{~g} / \mathrm{plant}$, respectively. The following means: $53.00 \pm 8.10,53.09 \pm 7.86,49.33 \pm 1.23$, $45.11 \pm 6.02,44.08 \pm 7.40,59.66 \pm 8.78,53.33 \pm 7.49$, $47.66 \pm 6.84, \quad 71.69 \pm 8.32, \quad 61.00 \pm 7.06, \quad$ and $30.66 \pm 8.22 \mathrm{~g} /$ plant were the biomass of the plants from the plots treated with $30 \mathrm{~g}$ of poultry litter $(\mathrm{F} 1)$, $60 \mathrm{~g}$ of poultry litter (F2), the combination of $10 \mathrm{~g}$ of mycorrhizae $+10 \mathrm{~g}$ of vivianite powder (MP), the combination of $10 \mathrm{~g}$ of mycorrhizae $+30 \mathrm{~g}$ of poultry litter (MF1), the combination of $10 \mathrm{~g}$ of mycorrhizae $+60 \mathrm{~g}$ of poultry litter (MF2), $10 \mathrm{~g}$ of vi-

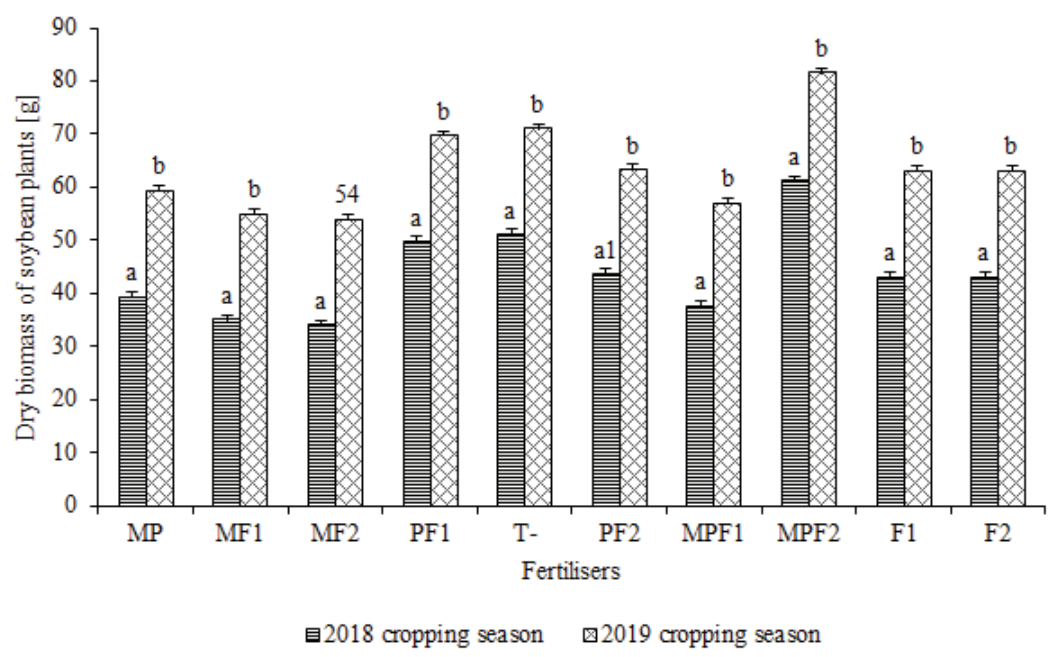

Figure 2. Dry biomass of soybean plants depending on fertiliser and cropping season

F1 - $30 \mathrm{~g}$ of poultry litter; F2 - $60 \mathrm{~g}$ of poultry litter; MP - the combination of $10 \mathrm{~g}$ of mycorrhizae $+10 \mathrm{~g}$ of vivianite powder; MF 1 - the combination of $10 \mathrm{~g}$ of mycorrhizae $+10 \mathrm{~g}$ of poultry litter; MF2 - the combination of $10 \mathrm{~g}$ of mycorrhizae $+60 \mathrm{~g}$ of poultry litter; PF1 $-10 \mathrm{~g}$ of vivianite powder $+30 \mathrm{~g}$ poultry litter; PF $2-10 \mathrm{~g}$ of vivianite powder $+60 \mathrm{~g}$ of poultry litter; MPF $1-10 \mathrm{~g}$ of mycorrhizae $+10 \mathrm{~g}$ of vivianite powder $+30 \mathrm{~g}$ of poultry litter; MPF2 $-10 \mathrm{~g}$ of mycorrhizae $+10 \mathrm{~g}$ of vivianite powder $+60 \mathrm{~g}$ of poultry litter; $\mathrm{T}+-$ chemical fertiliser, $\mathrm{T}-$ unfertilised plants. 
vianite powder $+30 \mathrm{~g}$ poultry litter (PF1), $10 \mathrm{~g}$ of vivianite poder $+60 \mathrm{~g}$ of poultry litter (PF2), $10 \mathrm{~g}$ of mycorhizae $+10 \mathrm{~g}$ of vivianite powder $+30 \mathrm{~g}$ of poultry litter (MPF1), $10 \mathrm{~g}$ of mycorrhizae $+10 \mathrm{~g}$ of vivianite powder $+60 \mathrm{~g}$ of poultry litter (MPF2), chemical fertiliser $(\mathrm{T}+)$ and unfertilised plants $(\mathrm{T}-)$, respectively. Plants that have received the MPF2 treatment exhibited the greatest biomass and it was about 1.16 fold higher than the biomass of the soybean plants derived from the $\mathrm{T}+$ treatment.

\section{Seed yield}

The seeds yielded by the soybean plants varied significantly $(p<0.05)$ depending on the fertiliser and the cropping year. Unfertilised plants exhibited significantly $(p<0.05)$ the lowest value $(1.05 \pm 0.40$ $\mathrm{t} / \mathrm{ha}$ ) of this production parameter. However, the soybean plants treated with $10 \mathrm{~g}$ of mycorrhizae $+10 \mathrm{~g}$ of vivianite powder $+60 \mathrm{~g}$ of poultry litter (MPF2) exhibited the highest seed yield $(2.99 \pm 0.49$ t/ha) (Table 3). The combination of poultry litter with mycorrhizae or vivianite powder better encreases the seed yield than the poultry litter without any combination. MPF2 treatment enhanced the seed yield about $20.08 \%$ and $184.76 \%$ compared to NPK chemical fertiliser and unfertilised plant, res- pectively. The soybean seed yield for the 2018 cropping season was higher $(2.09 \pm 0.63 \mathrm{t} / \mathrm{ha})$ than that of the 2019 cropping year $(1.81 \pm 0.51 \mathrm{t} / \mathrm{ha})$.

In this study, it was observed that all the parameters taken into consideration responded positively when the plots were fertilised as compared to the data from the control plot (unfertilised one). This means that the low nutrient available in the growing soil was improved by the different treatments either mineral or organic and as the results the agronomic traits considered were improved accordingly.

Previously, several reports (Ngo et al. 2014; Megueni et al. 2017; Tchuenteu et al. 2018) have found that the organic fertiliser improves productivity, the organic fertilisers contribute to maintaining soil fertility and thus the sustainability of agricultural production. These natural fertilisers are rich in mineral elements needed for plant growth. The beneficial effect of the organic fertiliser on soybean growth and seed yield would be related to the combined effect of improved soil properties and the availability of mineral nutrients. Also, some studies have shown that the local resources such as organic waste applied to poor tropical and acidic soil can provide the nutrients needed for plant growth $(\mathrm{Mu}-$ laji 2011). The poultry litter used was rich in min-

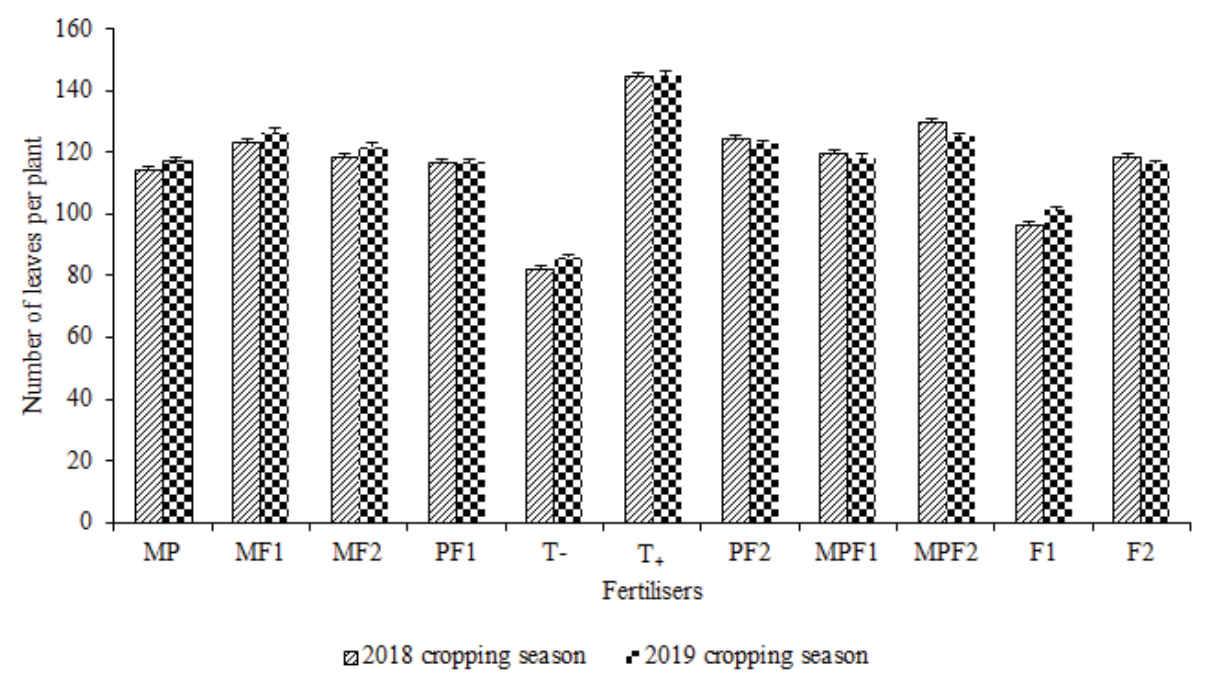

Figure 3. Number of leaves per plant depending on the fertiliser and the year of experimentation

$\mathrm{F} 1-30 \mathrm{~g}$ of poultry litter; F2 - $60 \mathrm{~g}$ of poultry litter; MP - the combination of $10 \mathrm{~g}$ of mycorrhizae $+10 \mathrm{~g}$ of vivianite powder; MF1 - the combination of $10 \mathrm{~g}$ of mycorrhizae $+10 \mathrm{~g}$ of poultry litter; MF2 - the combination of $10 \mathrm{~g}$ of mycorrhizae + $60 \mathrm{~g}$ of poultry litter; PF $1-10 \mathrm{~g}$ of vivianite powder $+30 \mathrm{~g}$ poultry litter; PF $2-10 \mathrm{~g}$ of vivianite powder $+60 \mathrm{~g}$ of poultry litter; MPF $1-10 \mathrm{~g}$ of mycorrhizae $+10 \mathrm{~g}$ of vivianite powder $+30 \mathrm{~g}$ of poultry litter; MPF $2-10 \mathrm{~g}$ of mycorrhizae $+10 \mathrm{~g}$ of vivianite powder $+60 \mathrm{~g}$ of poultry litter; $\mathrm{T}+-$ chemical fertiliser; $\mathrm{T}-$ unfertilised plants. Values of bands of each fertiliser affected by the same letter are not significantly different. 
eral elements needed for plant growth. It improves the physical characteristics of the soil (Vilmar et al. 2012) as well as its biological composition. Besides, Vilmar et al. (2012) studied the growth of soybean plants fertilised with poultry litter and revealed that the poultry litter provides the nitrogen that favors the accumulation of chlorophyll. Indeed, the photosyntic phenomenon requires chlorophyll, and therefore a higher chlorophyll content suggests the intensification of the photosyntic activities which results in the increase of plant productivity. Also, this would justify the beneficial effects of poultry litter on growth and seed yield of soybean observed in this study.

The beneficial effect of mycorrhizae on the growth and seed yield of soybean observed in this work was not surprising. Indeed, the positive effects of mycorrhizae on plants productivity have been demonstrated. Mycorrhizae are symbiotic associations between mycorrhizal fungi and plant roots. Mycorrhizae promote the hydromineral absorption of plants and thus improve plant growth and devel- opment (Megueni et al. 2011; Tchuenteu 2014; Tobolbai et al. 2018; Abakar et al. 2019).

The chemical analysis of vivianite powder used in this study was done by Yaya et al. (2015) and gave the following composition: $\mathrm{Fe}_{2} \mathrm{O}_{3}(68.72 \%), \mathrm{P}_{2} \mathrm{O}_{5}$ (9.17\%), $\mathrm{Al}_{2} \mathrm{O}_{3}(7.72 \%)$ and $\mathrm{SiO}_{2}(9.67 \%)$. Thus, in levels of phosphorus, it contains about $671.50 \mathrm{mg} / \mathrm{kg}$ non assimilated and $81.13 \mathrm{mg} / \mathrm{kg}$ assimilated phosphorus. The mineral elements contained in this rock powder would have improved the soil fertility and thus the productivity of soybean.

It was observed in the current study that the combination of poultry litter with mycorrhizae or vivianite powder better increases the growth and seed yield of soybean than poultry litter without any combination. One of the actions of mycorrhizae would be related to the solubilization of phosphate which would be more readily for uptake by the plants due to the elimination of acid phosphatase in the rhizosphere. It is possible that mycorrhizae by hydrolyzing phosphorylated mineral compound, allow plants to directly absorb the phosphorus that

$\mathrm{T}$ a $\mathrm{b} 1$ e 3

Soybean seed yield $[\mathrm{t} / \mathrm{ha}]$ depending on the fertiliser and the cropping season

\begin{tabular}{|l|c|c|c|}
\hline \multirow{2}{*}{ Fertilisers } & \multicolumn{2}{|c|}{ Soybean seed yield [t/ha] } & Mean \pm SD \\
\cline { 2 - 4 } T- & 2018 cropping season & 2019 cropping season & $1.05 \pm 0.40^{\mathrm{a}}$ \\
T+ & $1.06 \pm 0.41$ & $1.04 \pm 0.39$ & $2.49 \pm 0.37^{\mathrm{e}}$ \\
F1 & $2.66 \pm 0.38$ & $2.33 \pm 0.37$ & $1.31 \pm 0.39^{\mathrm{ab}}$ \\
F2 & $1.33 \pm 0.40$ & $1.30 \pm 0.38$ & $1.49 \pm 0.39^{\mathrm{abc}}$ \\
MP & $1.66 \pm 0.37$ & $1.33 \pm 0.42$ & $2.49 \pm 0.40^{\mathrm{abc}}$ \\
PF1 & $2.66 \pm 0.42$ & $2.33 \pm 0.38$ & $1.83 \pm 0.40^{\mathrm{abcd}}$ \\
PF2 & $2.00 \pm 0.39$ & $1.66 \pm 0.41$ & $1.83 \pm 0.39^{\mathrm{abcd}}$ \\
MF1 & $2.00 \pm 0.40$ & $1.67 \pm 0.39$ & $2.14 \pm 0.40^{\mathrm{bcde}}$ \\
MF2 & $2.29 \pm 0.39$ & $2.00 \pm 0.41$ & $2.49 \pm 0.42^{\mathrm{de}}$ \\
MPF1 & $2.66 \pm 0.42$ & $2.33 \pm 0.43$ & $2.31 \pm 0.42^{\text {cde }}$ \\
MPF2 & $2.33 \pm 0.39$ & $2.30 \pm 0.45$ & $2.99 \pm 0.49^{\mathrm{de}}$ \\
Mean \pm SD & $3.32 \pm 0.54$ & $2.66 \pm 0.44$ & $1.95 \pm 0.42^{\mathrm{a}}$ \\
\hline
\end{tabular}

SD - Standard deviation; F1 - $30 \mathrm{~g}$ of poultry litter; F2 - $60 \mathrm{~g}$ of poultry litter; MP - the combination of $10 \mathrm{~g}$ of mycorrhizae $+10 \mathrm{~g}$ of vivianite powder; MF 1 - the combination of $10 \mathrm{~g}$ of mycorrhizae $+10 \mathrm{~g}$ of poultry litter; MF2 - the combination of $10 \mathrm{~g}$ of mycorrhizae $+60 \mathrm{~g}$ of poultry litter; PF $1-10 \mathrm{~g}$ of vivianite powder $+30 \mathrm{~g}$ poultry litter; PF $2-10 \mathrm{~g}$ of vivianite powder $+60 \mathrm{~g}$ of poultry litter; MPF $1-10 \mathrm{~g}$ of mycorrhizae $+10 \mathrm{~g}$ of vivianite powder $+30 \mathrm{~g}$ of poultry litter; MPF $2-10 \mathrm{~g}$ of mycorrhizae $+10 \mathrm{~g}$ of vivianite powder $+60 \mathrm{~g}$ of poultry litter, $\mathrm{T}+-$ chemical fertiliser, $\mathrm{T}-$ unfertilised plants. Values of band columns affected by the same letter are not significantly different. 
was not accessible to them (Dalpé 2003). Inoculation of mycorrhizal fungi with vivianite powder and poultry litter would results in improving significantly the nitrogen and phosphorus uptake by the plant than when these fertilisers were used alone. Among the different combinations, $10 \mathrm{~g}$ of mycorrhizae + $10 \mathrm{~g}$ of vivianite powder $+60 \mathrm{~g}$ of poultry litter (MPF2) gave the highest response in term of plant growth. By producing MPF2 fertiliser for growing soybean, we will not only contribute to improving the growth and seed yield of this crop but also valorize the local resources as well as protecting our environment. However, the effects of the fertilisers used in this study on the physico-chemical properties of soybean seeds need to be investigated.

\section{CONCLUSIONS}

The soil of the locality of Bini-Dang (Cameroon) is not favorable for growing soybean because it is an acid soil and poor in some nutrients such as $\mathrm{N}$ and $\mathrm{P}$. The growth and seed yield of soybean varied significantly depending on the fertiliser and the year of experimentation. The combined application of $10 \mathrm{~g}$ of mycorrhizae $+10 \mathrm{~g}$ of vivianite powder $+60 \mathrm{~g}$ of poultry litter (MPF2) resulted in the highest plant growth response. MPF2 treatment increased the seed yield of soybean about $20.08 \%$ and $184.76 \%$ as compared to the data obtained from the treatment using the NPK chemical fertiliser and from the unfertilised plot, respectively. Thus, MPF2 fertiliser can be employed to replace the mineral fertilisers in an attempt to boost the production of soybean while reducing the production cost. Our future study will focus on the effects of MPF2 natural fertiliser on the physico-chemical properties of the soybean seeds.

\section{REFERENCES}

ABAKAR, A.S. -MEGUENI, C. - KOSMA, P. - TCHUENTEU, T.L. 2019. Response of two cotton varieties on mycorrizal inoculation at Sudano-Sahelian savannah of Cameroon. In East African Scholars Journal of Agriculture and Life Sciences, vol. 2, no. 3, pp. 145-154.

AFNOR, 1984. Recueil de normes françaises. Produits agricoles alimentaires: Directive générale pour le dosage de l'azote avec minéralisation selon la méthode de Kjedahl. AFNOR, Paris(France).

AFNOR, 1986. Recueil des normes françaises. Eaux-Mé- thodes d'essai. AFNOR, Paris(France).

DALPE, Y. 2003. Subsidiary body on scientific technical and technological advice (SBTTA). In BLUMWALD, E. (Ed.), Convention on Biological Diversity. Macmillan, London, pp. 100-103.

DEROGOH, N.-A.N. - MEGUENI, C. - TCHUENTEU, T.L. 2018. Study of intercropping systems castor oil and Legumes on seeds yield and yield related traits in two agroecological zones of Cameroon. In Scholars Journal of Agriculture and Veterinary Sciences, vol. 5, no. 6, pp. 352-368. DOI: 10.21276/sjavs.2018.5.6.11.

DEVANI, M.B. - SHISHOO, J.C. - SHAL, S.A. - SUHAGIA, B.N. 1989. Spectrophotometrical method for determination of nitrogen in Kjeldahl digest. In Journal of AOAC International, vol. 72, pp. 953-956.

GILLER, DASHIELL, 2007. Glycine $\max (\mathrm{L})$ Merill. Fiche de Protabase. In VAN DER VOSSEN, H.A.M. \& MKAMILO, G.S. (Eds.), PROTA (Plant resources of Tropical Africa/Ressources Végétales de l'Afrique Tropicale), Wageningen, Pays Bas.

JUNG, S.C. - MARTINEZ-MEDINA, A. - LOPEZ-RAEZ, J.A. - POZO, M.J. 2012. Mycorrhiza-induced resistance and priming of plant defenses. In Journal of Chemical Ecology, vol. 38, pp. 651-664. DOI: 10.1007/s10886012-0134-6.

KAMDEM, K.F. 2017. Effets des doses de mycorhizes et de la poudre de vivianite sur la productivité du soja dans la localité de Bini-Dang (Ngaoundéré Cameroun). Mémoire Soutenu de MASTER, Université de Ngaoundéré Cameroun, Faculté des Sciences, Département de Sciences Biologiques.

MBONIGABA, M.J.J. - NZEYIMANA, I. - BUCAGU, C. CULOT, M. 2009. Caractérisation physique, chimique et microbiologique de trois sols acides tropicaux du Rwanda sous jachères naturelles et contraintes à leur productivité. In Biotechnology, Agronomy, Society and Environment, vol. 13 , no. 4 , pp. $545-558$.

MEGUENI, C. - AWONO, E.T. - NDJOUENKEU, R. 2011. Effet simultané de la dilution et de la combinaison du Rhizobium et des mycorhizes sur la production foliaire et les propriétés physico-chimiques des jeunes feuilles de Vigna unguiculata (L.) Walp. In Journal of Applied Biosciences, vol. 40, pp. 2668-2676.

MEGUENI, C. - NGAKOU, A. - MAKALAO, M.M. KAMENI, T.D. 2006. Response of soybean (Glycine $\max$ L.) to soil solarization and rhizobial inoculation at Dang Ngaoundéré, Cameroun. In Asian Journal of Plant Science, vol. 5, no. 5, pp. 832 -837. DOI: 10.3923/ ajps.2006.832.837.

MEGUENI, C. - TCHUENTEU, T.L. - NOUBISSIE, E. MAIMOUNA, A. - BACHIROU, H. 2017. Field productivity of carrot (Daucus carota L.) in Adamawa Cameroon and chemical properties of roots according to chicken manure pretreatments and vivianite powder. In Journal of Agriculture and Veterinary Science (IOSR-JAVS), vol. 10, no. 5, pp. $16-23$. DOI: 10.9790/2380-1005011623.

MULAJI, K.C. 2011. Use of household biowaste composts to improve acid soils fertility of the Province of Kinshasa (Dem. Rep. of Congo) (Ph.D. Thesis). Gembloux, Belgium: University of Liège, Gembloux Agro-Bio Tech., $172 \mathrm{p}$.

NANDA, K.F. - ADRIANO, S.N. 2014. Management of soil acidity of South American soils for sustainable crop production. In Advances in Agronomy, vol. 128, pp. 221 -275. DOI: 10.1016/B978-0-12-802139-2.00006-8.

NGO, N.L. - NGO, B.M. - FANKEM, H. - ADAMOU, S. KAMGUIA, K. - NGAKOU, A. - NWAGA, D. - ETOA, 
F-X. 2014. Inoculation and screening of indigenous Bambara Groundnut (Vignasubterranea) nodulating bacteria for their tolerance to some environmental stresses. In American Journal of Microbiological Research, vol. 3, no. 2, pp. 65-75. DOI: 10.12691/ajmr-3-2-5.

NWAGA, D. - ENGELMANN, F. - HAMON S. - DJIETO, L.C. 2007. Biotechnologies et maîtrise des intrants agricoles en Afrique centrale. Book of abstracts. Reseau 'BIOVEG', AUF/IRD/Universite de Yaoundé /IRAD, Yaoundé, Cameroon. Avaiable at: http://www. bioveg. auf.org.

OLINA, B.J.P. - M'BIANDOUN, A. - EKORONG, J.A. ASFOM, P. 2008. Evolution de la fertilité des sols dans un système cotonnier céréales au Nord Cameroun : diagnostic et perspective In Tropicultura, vol. 26, no. 4, pp. $240-245$.

RODIER, J. 1978. L'analyse de l'eau: chimie, physico chimie, bactériologie, biologie. $6^{\text {ème }}$ éd., Dunod Technique, Paris (France).

ROUX, J.L. 2002. Soybean, a new leading food. In Storage of nutrient. Comparing methods and technologies, pp. $600-601$.

SHENG, M. - TANG, M. - CHEN, H. -YANG, B. -ZHANG, F. - HUANG, Y. 2008. Influence of arbuscular mycorrhizae on photosynthesis and water status of maize plants under salt stress. In Mycorrhiza, vol. 18, pp. 287-296. DOI: $10.1007 / \mathrm{s} 11738-015-1932-6$.

TCHUENTEU, T.L. 2014. Caractérisation agronomique des accessions locales de ricin (Ricinuscommunis L.) cultivées en champ dans le Grand Nord Cameroun et évaluation des propriétés physico-chimiques des graines. Thèse de doctorat Ph.D. Faculté des sciences. Université de Ngaoundéré Cameroun.

TCHUENTEU, T.L. - MEGUENI, C. - NOUBISSIE, E. WAMKOUA, M.M. 2018. Study on physico-chemical properties of composts and their effects on growth, yield and fruits quality of Capsicum annum L. at Dang local- ity (Ngaoundéré Cameroon). In Journal of Agriculture and Veterinary Science (IOSR-JAVS), vol. 11, no. 11, pp. 26-35. DOI: 10.9790/2380-1111022635.

TIEN, H.H. - HIEN, T.M. - SON, M.T. - HERRIDGE, D. 2002. Inoculation and N2 fixation of soybean and mungbean in the Esatern region of South Vietnam. In HERRIDGE, D. (Ed.), $109^{e}$ Proceedings (ACIAR) Inoculation and nitrogen at legumes in Vietnam.

TOBOLBAI, R. - ADAMOU, S. - NGAKOU, A. 2018. Morphological and structural of indigenous endomycorrhiza communities associated to maize [Zea mays (L.)] in Northern Cameroonian soils. In Journal of Animal \& Plant Sciences, vol. 38, no. 1, pp. 6057-6073.

VASSILEV, P. -VASSILEVA, M. 2003. Biotechnological solubilization of roch phosphate on media contening agroindustrial. In Applied Microbiology and Biotechnology, vol. 61, no. 5-6, pp. 435-40. DOI: 10.1007/s00253003-1318-3.

VILMAR, A. - RAGAGNIM, D. - GERALDO DE SENA, J. - DANYLLO, S.D. -WESLLEY, F.B. - PHELIPE, D.M N. 2013. Growth and nodulation of soybean plants fertilized with poultry litter. In Ciência e Agrotecnologia, vol. 37, no. 1, pp. 17-24. DOI: 10.1590/S141370542013000100002 .

WATIER, B. 1982. A nutritional equilibrium in Africa. How? Neuilly Sur Seine, Hoffman-La Roche.

YAYA, F. - NGUETNKAM, J.P. - TCHAMENI, R. BASGA, S.D. - PENAYE, J. 2015. Assessment of the fertilizing effect of Vivianite on the growth and yield of the Bean "Phaseolus vulgaris" on Oxisoils from Ngaoundere (Central North Cameroon). In International Research Journal of Earth Sciences, vol. 3, no. 4, pp. $18-26$.

Received: July 24, 2020

Accepted: October 29, 2020 